\title{
PERILAKU MASYARAKAT PINGGIRAN HUTAN TERHADAP TAMAN NASIONAL KERINCI SEBLAT DI KECAMATAN GUNUNG TUJUH
}

\author{
Agel Vidian Krama', Nurul Qamilah ${ }^{2}$ \\ Institut Teknologi Sumatera ${ }^{12}$ \\ agel.vidiankrama@gt.itera.ac.id ${ }^{1}$
}

\begin{abstract}
ABSTRAK
Penelitian ini bertujuan untuk memperoleh gambaran perilaku masyarakat pinggiran hutan terhadap Taman Nasional Kerinci Seblat Di Kecamatan Gunung Tujuh tentang perilaku positif dan perilaku negatif yang dilakukan oleh masyarakat pinggiran hutan terhadap Taman Nasional Kerinci Seblat. Jenis penelitian ini adalah Penelitian deskriptif kualitatif, dalam pengambilan informan dengan teknik snowball. Alat pengumpul data menggunakan cara wawancara, observasi dan dokumentasi untuk memperoleh data pada daerah penelitian. Teknik analisis data yang dilakukan adalah teknik analisa model Milles dan Huberman yaitu reduksi data, display data, dan penarikan kesimpulan. Hasil penelitian menunjukkan bahwa: (1) Perilaku positif masyarakat pinggiran hutan terhadap Taman Nasional Kerinci Seblat yang ada di Kecamatan Gunung Tujuh: a) Masyarakat di Kecamatan Gunung Tujuh telah melarang apabila ada dari anggota masyarakat yang melakukan pembukaan lahan baru, b) Masyarakat pada Kecamatan Gunung Tujuh sudah melakukan reboisasi. (2). Perilaku negatif masyarakat pinggiran hutan terhadap Taman Nasional Kerinci Seblat di Kecamatan Gunung Tujuh: a) Masyarakat masih berladang pada kawasan Gunung Tujuh yang termasuk ke dalam zonasi Taman Nasional Kerinci Seblat, b) Masyarakat di Kecamatan Gunung Tujuh masih ada yang melakukan penebangan pohon pada kawasan Taman Nasional Kerinci Seblat, c) Masyarakat yang bermata pencarian sebagai petani serta memiliki hewan piaraan masih mengembalakan ternaknya pada kawasan Taman Nasional Kerinci Seblat, d) Masyarakat Gunung Tujuh masih membuang benda-benda yang dapat merusak kawasan TNKS, e) Masyarakat Gunung Tujuh masih melakukan kegiatan berburu hewan pada kawasan Taman Nasional Kerinci Seblat. f) Masyarakat yang bermata pencarian petani sudah melakukan tebang pilih dalam pengambilan kayu yang terdapat pada kawasan Taman Nasional Kerinci Seblat. Kesimpulan Sebelum adanya kawasan TNKS masyatakat sudah bermata pencaharian sebagai petani dan dengan adanya TNKS masyarakat berperilaku positif dengan menjaga kelestarian TNKS akan tetapi masih ada masyarakat yang berperilaku negatif dikarenakan dorongan kebutuhan hidup.
\end{abstract}

Kata Kunci : Masyarakat, Perilaku 


\begin{abstract}
This study aims to study the community about Kerinci Seblat National Park in Gunung Tujuh subdistrict about activities and negative activities conducted by the community towards Kerinci Seblat National Park. The research is a qualitative descriptive study, in decision informant with snowball technique. Means of collecting data using interviews, observation and documentation to obtain data on the study area. Data analysis technique is a technique performed Milles and Huberman model analysis of data reduction, data display, and conclusion. The results showed that: (1) A positive behavior forest fringe communities of the Kerinci Seblat National Park in the district of Gunung Tujuh: a) Communities in the District of Gunung Tujuh has prohibited if any of the members of the community who do clearing new land, $b$ ) People in Gunung Tujuh District have done reforestation. (2). These negative attitudes towards forest fringe communities Kerinci Seblat National Park in the district of Gunung Tujuh: a) People are still farming in the area of Gunung Tujuh, which belong to the zoning Kerinci Seblat National Park, b) Communities in the District of Gunung Tujuh they were cutting trees in the area of Kerinci Seblat National Park, c) Communities that have search as farmers and have pets, they took off their animals at the area Kerinci Seblat National Park, d) Public Gunung Tujuh still throwing objects which can damage TNKS area, e) Community Gunung Tujuh still hunting animals in Kerinci Seblat National Park. f) People who work as farmers have been doing selective in making wood contained in the Kerinci Seblat National Park. Conclusion Before the existence of the KSNP community, they were already earning a living as farmers and with the presence of the KSNP community behaved positively by preserving the TNKS preservation but there were still people who behaved negatively due to the necessity of life.
\end{abstract}

Keywords: Community, Behavior

\section{PENDAHULUAN}

Sumberdaya alam merupakan modal dasar pembangunan nasional sumberdaya alam tersebut harus di manfaatkan secara optimal bagi kesejahteraan rakyat kesinambungan, keserasian, keselarasan dan keseimbangan baik secara manusia dan baik penciptanya manusia dengan masyarakat, maupun manusia dengan lingkungannya (Neni, 1999). bakar, bangunan dan juga bahan atau sumber protein ekstra dan bagian yang lain.
Hutan dapat juga dijadikan sebagai lahan yang dapat di tanami bermacam bahan pangan untuk keperluan konsumsi, memang hutan itu merupakan mata pencaharian bagi masyarakat pinggiran TNKS, yang gunanya untuk pemenuhan kebutuhan hidupnya. Secara ekologis TNKS mempunyai nilai atau manfaat yang sangat penting bagi cadangan keanegaragaman hayati, karena kawasan ini memiliki tipe ekosistem yang cukup lengkap mulai dari hutan dataran rendah (tropical lowlend forest) sampai hutan 
pegunungan (sub alpin) dengan puncak tertinggi Gunung Kerinci (3.805 m dpl). Kekayaan ekosistem dengan keanekaragaman hayati di TNKS sudah di akui baik secara nasional maupun internasional.

Guna menciptakan kondisi lingkungan hidup dalam keadaan serasi dan seimbang faktor manusia yang sangat menentukan pelestarian hutan itu sendiri, karena manusia merupakan unsur penentu utama dalam ekosistem. Masalah lingkungan hidup timbul jika terdapat ketidak seimbangan antara kebutuhan hidup manusia dengan produksi dan sumber daya yang serakah dan teknologi yang menghasilkan limbah yang berlebihan. Hal yang juga sangat menentukan adalah mental dan perilaku dari penduduk yang tidak bertanggung jawab sehingga melakukan pengrusakan lingkungan hidup karena disebabkan dari segi ekonomi seperti kurang tercukupi kebutuhan hidup. Di wilayah desa tidak di temui hutan sisa di luar hutan TNKS. Banyak masyarakat yang bermata pencarian petani di sekitar hutan membuka hutan untuk areal pertanian dan ladang. Kawasan TNKS untuk Propinsi Jambi secara administratif terletak di Kabupaten Kerinci yang mempunyai kawasan yang luas di kawasan tersebut. Masyarakat di Kabupaten Kerinci tepatnya di Kecamatan Gunung Tujuh secara umum Kehidupan mereka tergantung pada hutan di kawasan TNKS. Sebagian besar masyarakat pingiran hutan kawasan TNKS bermata pencarian sebagai petani, mereka menggunakan kawasan TNKS sebagai areal pertanian.

Kenyataan menunjukkan, bahwa terjadi kerusakan hutan umumnya berpangkal dari pemanfaatan sumberdaya hutan tanpa memikirkan dampaknya seperti masalah pengambilan hasil hutan yang secara terus menerus dan akan mengakibatkan terjadinya longsor dan banjir. Proses kerusakan akan terus terjadi seiring dengan pertumbuhan penduduk yang tidak terkendali. Bertambahnya penduduk maka kebutuhannya akan bertambah, dan kebutuhan terus mendesak, sehingga manusia dalam memenuhi kebutuhannya melakukan tindakan yang membawa dampak yang negatif terhadap lingkungan yaitu pemanfaatan hutan dengan membuka lahan untuk pertanian dengan cara penebangan liar, eksploitasi hutan yang kurang tertib, konversi hutan untuk kegiatan pertanian dan pembakaran hutan.

Walaupun pemerintah telah melakukan usaha untuk melestarikan hutan dengan berbagai kegiatan, namun kenyataan menunjukkan bahwa kerusakan hutan akhir ini sering terjadi, di pihak pemerintah kerusakan hutan sering terjadi di sebabkan karena kurangnya perhatian pemerintah terhadap dampak yang akan timbul terhadap lingkungan hutan akibat pembukaan lahan yang di lakukan dengan cara pembakaran dan kurangnya pengawasan terhadap daerah 
hutan yang dilindungi oleh pihak kehutanan.

Sehingga pentingnya menjaga perilaku masyarakat dalam menjaga kawasan hutan, karena hutan merupakan kekayaan alam yang perlu diperhatikan dan dipelihara dengan sebaiknya, karena apa yang ada dimuka bumi itu harus diperhatikan keberadaannya salah satunya hutan. Kalau tidak diperhatikan akan berdampak juga terhadap manusia sekitarnya. Tetapi kalau keberadaan hutan diperhatikan dengan baik, maka akan memberi keuntungan kepada masyarakat itu sendiri. Dan dapat kita lihat pada kenyataan sekarang ini banyak masyarakat petani yang berada di pinggiran hutan melakukan pembabatan hutan guna membuka lahan baru demi memenuhi kebutuhan hidupnya, padahal hal tersebut hanya memberi keuntungan sementara dan untuk kepentingan pribadi, maka dari itu diperlukan partisipasi masyarakat dalam menjaga dan memperhatikan keberadaan hutan dilingkungannya. Berdasarkan hal tersebut penulis tertarik untuk mengkaji tentang petani yang berada di sekitar kawasan Taman Nasional Kerinci Seblat, dalam sebuah penelitian dengan judul Perilaku Masyarakat Pinggiran Hutan Di Kecamatan Gunung Tujuh Terhadap Kerusakan Taman Nasional Kerinci Seblat.

\section{METODE PENELITIAN} Jenis Penelitian

Penelitian ini tergolong penelitian Deskriptif. Sesuai dengan pembatasan perumusan dan tujuan penelitian yang telah di jelaskan, maka penelitian ini tergolong penelitian "Kualitatif", yaitu berusaha mengungkapkan bagaimana Perilaku Masyarakat Pinggiran Hutan Di Kecamatan Gunung Tujuh Terhadap Kerusakan Taman Nasional Kerinci Seblat.

\section{Lokasi dan Informan Penelitian}

Populasi penelitian yaitu jumlah kepala keluarga yang ada pada tiga kecamatan yang Lokasi penelitian berada di Kecamatan Gunung Tujuh, Kabupaten Kerinci Provinsi Jambi. Penelitian ini dilakukan di tiga desa yang ada di Kecamatan Gunung Tujuh yakni desa Pelompek, desa Pesisir Bukit, dan desa Pauh Tinggi. Pemilihan lokasi tersebut karena pada tiga desa ini merupakan desa yang terdekat jaraknya dengan kawasan TNKS, serta di tiga desa ini mata pencaharian masyarakatnya di dominasi oleh mata pencaharian sebagai petani.

Penentuan informan dilakukan secara purposif dengan menggunakan teknik bola salju teknik snow ball, yang sifatnya bergulir menggelinding seperti bola salju. Adapun yang menjadi informan dalam penelitian ini adalah masyarakat yang berada diwilayah yang berdekatan dengan kawasan TNKS serta masyarakat yang bekerja sebagai petani 
di kawasan TNKS. Proses penjaringan informan melalui informasi akan dihentikan apabila tidak ditemukan lagi informasi-informasi baru yang berbeda dari para informan. Jumlah informan yang termasuk ke dalam penelitian ini yaitu sebanyak 11 (sebelas) orang.

\section{Teknik Pengumpul Data}

Sebagaimana yang dikemukakan di atas, peneliti menggunakan metode kualitatif menurut Glasser dan Straus dalam Iswandi (2009) maka teknik pengumpulan data dapat dikumpulkan melalui :

1. Wawancara. Dalam mengumpulkan data melalui wawancara penulis mengajukan pertanyaan langsung kepada informan sesuai dengan data yang dibutuhkan. Menurut Patton dalam Moleong (2005) wawancara dapat dilakukan atas tiga cara yakni a) wawancara informal, b) wawancara mengunakan petujuk umum, dan c) wawancara baku terbuka.

2. Observasi (pengamatan langsung dilapangan). Observasi dilakukan dengan cara mengamati langsung Perilaku Masyarakat Pinggiran Hutan Di Kecamatan Gunung Tujuh Terhadap Kerusakan Taman Nasional Kerinci Seblat sambil membandingkan data yang didapat berdasarkan hasil wawancara.

3. Dokumentasi merupakan salah satu sumber data yang dapat digunakan untuk melengkapi data penelitian. Perilaku Masyarakat Pinggiran
Hutan Di Kecamatan Gunung Tujuh Terhadap Kerusakan Taman Nasional Kerinci Seblat. Menurut Moleong (2005), ada lima alasan mengapa dokumen digunakan sebagai sumber data dalam penelitian, yaitu : a) selalu tersedia dan dapat digunakan kapan saja, b) merupakan informasi yang stabil, c) merupakan sumber informasi yang lebih lengkap, d) bersifat resmi dan menyeluruh, dan e) tidak ada sangsi terhadap penelitian.

\section{Teknik Analisis Data}

Analisis data penelitian kualitatif diawali dengan kegiatan mengumpulkan data (data collection) yaitu mulai dari pencarian informan umum selama grand tour, observasi terfokus (mini tour) sampai pada observasi terseleksi. Dengan demikian data yang telah direduksi akan memberikan gambaran yang lebih jelas, dan mempermudah peneliti untuk melakukan pengumpulan data selanjutnya.

Teknik analisis data penelitian ini mengunakan model Miles dan Huberman. Menurut Miles dan Huberman dalam Emzir (2011) ada tiga macam kegiatan dalam analisis data kualitatif, yaitu:

1. Reduksi data. Reduksi data adalah suatu bentuk analisis yang mempertajam, memilih, memfokuskan, membuang, dan menyusun data dalam suatu cara di mana kesimpulan akhir dapat digambarkan dan diverifikasikan. 
Reduksi data merujuk pada proses pemilihan, pemfokusan, penyederhanaan, abstraksi dan pentransformasian data mentah yang terjadi dalam catatan lapangan secara tertulis.

2. Model Data (data display). Data display ialah menyajikan data dalam bentuk tabel, grafik, phie chard, pictogram, network, chart, dan sejenisnya. Melalui penyajian data tersebut, maka data terorganisasikan, tersusun dalam pola hubungan, sehingga akan mudah untuk dipahami. Semua dirancang untuk mengumpulkan informasi dalam suatu yang dapat diakses secara langsung, bentuk yang praktis, dengan demikian peneliti dapat melihat apa yang terjadi dan dapat dengan baik menggambarkan kesimpulan yang dijustifikasikan maupun bergerak ke analisis tahap berikutnya model mungkin menyarankan yang bermanfaat.

3. Penarikan Kesimpulan (conclusion verification). Kesimpulan dalam penelitian kualitatif merupakan temuan baru, dan temuan dapat berupa deskripsi atau gambaran suatu obyek yang sebelumnya masih remang-remang atau gelap, sehingga setelah diteliti menjadi jelas, dapat berupa hubungan kausal atau interaktif, hipotesis atau teori.

Teknik analisis model Miles dan Huberman ini dapat diilustrasikan seperti pada Gambar 1. berikut ini

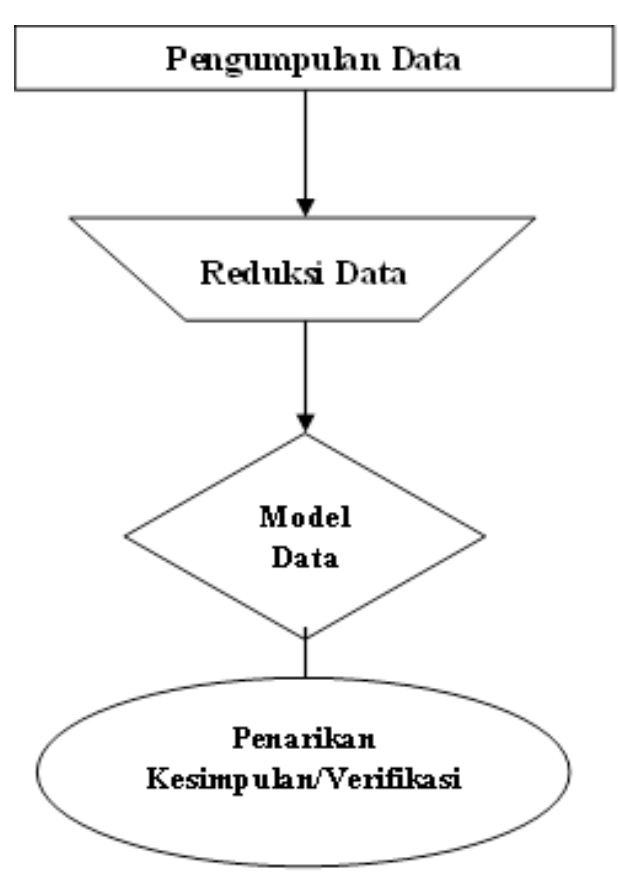

Gambar 1. Model Miles dan Huberman

\section{HASIL DAN PEMBAHASAN}

Taman Nasional Kerinci Seblat berdasarkan sejarah kawasannya terdiri dari 13 (tiga belas) kelompok hutan yang merupakan bagian dari hutan lindung yang tercantum dalam Registrasi Kelompok Hutan pada masa pemerintahan Belanda, Register GB (Goverment Besluit) tahun 1921 sampai dengan 1936, anatara lain: a) Dari 17 kelompok hutan : hutan register 19211926, b) Dari CA dan SM yang ditetapkan 1978-1926, c) Dari beberapa kawasan HP dan HL. Berdasarkan undang-undang No.5 tahun 1990 bahwa taman nasional adalah kawasan pelestarian alam yang dikelola dengan sistem zonasi. 
Daerah penelitian adalah Kecamatan Gunung Tujuh yang diwakili oleh 4 ( empat) Desa, yaitu: Desa Pauh Tinggi, Desa Pesisir Bukit dan Desa Pelompek yang pada tahun 2011 ini memekarkan diri menjadi dua desa yaitu Desa Pelompek dengan Desa Sungai Jernih. Dimana subjek penelitian adalah masyarakat yang bermata pencarian sebagai petani pada Kecamatan Gunung Tujuh yang tersebar pada empat desa tersebut, yaitu: Desa Pelompek, Desa Sungai Jernih, Desa Pesisir Bukit, dan Desa Pauh Tinggi. Data yang penulis kumpulkan baik berdasarkan hasil wawancara, observasi ataupun data-data yang diperoleh dari dinas atau instansi terkait, maka hasil analisis mengenai pertanyaan penelitian pada pokok bahasan sebelumnya akan penulis bahas lebih lanjut dalam bentuk uraian berikut.

\section{Perilaku Masyarakat Pinggiran Hutan Terhadap Kawasan Taman Nasional Kerinci Seblat}

Masyarakat di Kecamatan Gunung Tujuh mayoritas penduduknya bekerja sebagai petani. Pekerjaan sebagai petani telah mereka lakukan semenjak turun temurun, masyarakat tersebut melakukan kegiatan bertani sudah dimulai semenjak tahun 1960 an. Hal ini dibuktikan dari tingginya jumlah mata pencarian sebagai petani dibandingkan pekerjaan lainnya, hal tersebut dapat dilihat melalui data dari pihak BPS bahwa pertanian menjadi mata pencarian utama. Masyarakat yang bermata pencarian sebagai petani pada waktu itu masih pulang pergi dan belum menetap pada daerah pertanian mereka, karena mereka memiliki rumah yang jauh dari areal pertanian. Sehingga masyarakat pada saat itu belum menetap. Masyarakat di Kecamatan Gunung Tujuh menganggap bahwa mata pencarian petani merupakan penopang dalam pemenuhan kebutuhan hidupnya semenjak turun temurun dari orang tua mereka, sehingga apabila masyarakat tersebut di gusur dari lahan pertanian mereka berharap pemerintah menyediakan lahan lainnya sebagai ganti ladang mereka. Masyarakat pun bersedia pindah dari lokasi mereka sekarang apabila pemerintah menyediakan lahan ganti bagi ladang mereka. Berikut di bawah ini merupakan dokumentasi wawancara peneliti pada saat di lapangan.

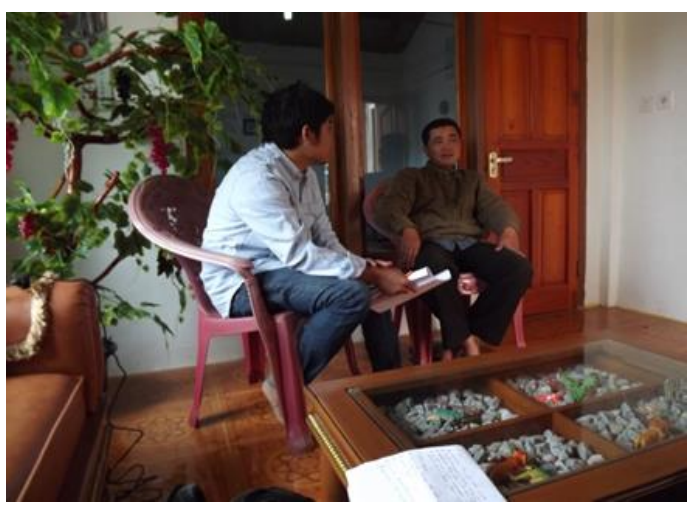

Gambar 2. Kepala Desa Pesisir Bukit

Dari hasil penelitian terhadap
masyarakat yang bermata pencarian
sebagai petani ditemukan bahwa
perilaku masyarakat tersebut disebabkan
karena bertani merupakan mata


pencarian mereka satu-satunya dalam memenuhi kebutuhan hidupnya, sehingga tidak ada alternatif lain bagi mereka kecuali bertani pada lahan ladang mereka yang termasuk ke dalam zonasi kawasan Taman Nasional Kerinci Seblat. Mereka berharap kepada pemerintah agar memperhatikan mereka, karena kalau mereka digusur mereka meminta kepada pemerintah untuk menyediakan lahan pengganti bagi ladang mereka yang termasuk kedalam zonasi kawasan TNKS.

\section{Perilaku Positif Masyarakat Pinggiran Hutan Terhadap Kawasan Taman Nasional Kerinci Seblat}

Adapun bentuk-bentuk perilaku positif yang dilakukan masyarakat yang bermata pencarian sebagai petani yaitu:

1. Masyarakat sudah mulai melarang yang namanya pembukaan lahan baru, karena masyarakat takut ditangkap oleh petugas Taman Nasional Kerinci Seblat sehingga masyarakat tetap menggunakan lahan ladang peninggalan orang tua mereka yang dulu sebagai kawasan ladang mereka hingga saat ini.

Dari pernyataan informan yang peneliti temukan dilapangan, masyarakat yang bermata pencarian sebagai petani pada umumnya hanya menggunakan lahan mereka yang lama sebagai areal ladang mereka. Dan apabila ada diantara mereka yang membuka lahan baru, maka warga masyarakat yang bermata pencarian petani yang lain akan memperingati mereka untuk tidak membuka lahan baru,

2. Masyarakat yang bermata pencarian sebagai petani sudah melakukan yang namanya kegiatan reboisasi, meskipun dalam hal ini masyarakat yang bermata pencarian sebagai petani bekerjasama dengan KODIM guna mensukseskan program pemerintah dalam melakukan rebiosasi. Dalam melakukan program reboisasi ini masyarakat di berikan bibit pohon Surian, Petai, dan Gaharu. Setiap dilakukan penanaman 1 pohon dihargai $\mathrm{Rp}$. 1000,00. Penanaman itu dilakukan pada areal ladang para petani.

Untuk lebih jelasnya kegiatan yang dilakukan masyarakat dapat dilihat melalui dokumentasi peneliti di bawah ini.

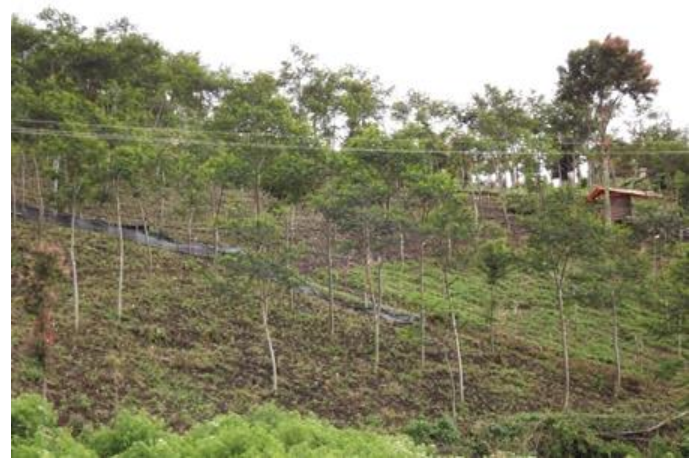

Gambar 3. Lahan Pertanian

Masyarakat

menyadari

keberadaan pohon pelindung sangat penting pada kawasan Taman Nasional Kerinci Seblat. Karena pada Gunung Tujuh terdapat Danau Gunung Tujuh diatasanya dan dikaki Gunung Tujuh tersebut tepat dibawahnya terdapat Desa 
Sungai Jernih. Apabila hutan yang ada disekeliling danau itu rusak, dan tidak dapat menahan debit air di Danau Gunung Tujuh tersebut sewaktu-waktu Danau itu akan jebol sehingga dapat mengancam kehidupan masyarakat yang berada di bawah nya.

Berdasarkan hasil penelitian yang telah penulis lakukan, masyarakat yang bermata pencarian sebagai petani mengemukakan bahwa mereka melakukan kegiatan seperti melarang pembukaan lahan baru, dan kegiatan reboisasi karena takut akan ditangkap oleh petugas Taman Nasional Kerinci Seblat serta masyarakat menyadari akan bahaya yang ditimbulkan apabila hutan di sekitar Gunung Tujuh gundul. Masyarakat takut nantinya air pada Danau Gunung Tujuh merembes dan menggenangi pemukiman warga yang tepat berada di bawahnya karena dapat mengancam kehidupan masyarakat yang tinggal di kaki Gunung Tujuh tersebut.

$$
\text { Dari hasil penelitian di }
$$

Kecamatan gunung Tujuh dapat disimpulkan bahwa masyarakat pada empat desa yaitu Desa Pelompek, Desa Pesisir Bukit, Desa Sungai Jernih, dan Desa Pauh Tinggi telah melakukan kegiatan positif pada kawasan Taman Nasional Kerinci Seblat yaitu: masyarakat telah melakukan reboisasi, masyarakat sudah melarang pembukaan lahan baru, masyarakat juga sudah melakukan tebang pilih dalam pengambilan kayu hutan.

\section{Perilaku Negatif Masyarakat} Pinggiran Hutan Terhadap Kawasan Taman Nasional Kerinci Seblat

Adapun bentuk-bentuk perilaku positif yang dilakukan masyarakat yang bermata pencarian sebagai petani yaitu:

1. Masyarakat masih tetap saja menggunakan lahan yang termasuk zonasi kawasan Taman Nasional Kerinci Seblat sebagai ladang mereka. Karena masyarakat yang bermata pencarian sebagai petani beranggapan bahwa mereka mengelola lahan tersebut jauh sebelum TNKS itu ada. Dan masyarakat merasa bahwa TNKS merebut lahan pekerjaan mereka, dengan mengklaim ladang mereka sebagi kawasan TNKS.

2. Masyarakat pada Kecamatan Gunung Tujuh masih ada yang melakukan penebangan pohon pada kawasan TNKS. Hal ini disebabkan karena pada pembangunan rumah mereka menggunakan kayu yang ada pada kawasan TNKS sebagai bahan baku. Dan juga dalam pembangunan sarana umum seperti Masjid, masyarakat ber gotong royong mengambil kayu hutan untuk bahan baku pembangunan masjid.

3. Masih terdapatnya masyarakat Gunung Tujuh yang mengembalakan ternaknya pada kawasan Taman Nasional Kerinci Seblat. Masyarakat yang bermata pencarian petani pada umumnya memiliki hewan ternak yang 
pengembalannya dilakukan pada kawasan Taman Nasional Kerinci Seblat, karen ahanya pada kawasan Taman Nasional Kerinci Seblat terdapat padang rumput untuk makanan ternak mereka dengan kualitas yang bagus.

4. Masyarakat Gunung Tujuh masih terdapat yang membuang bendabenda yang dapat merusak kawasan TNKS. Masyarakat yang bermata pencarian petani sering sekali tidak mengumpulkan sampah berupa plastik pembungkus makanan yang mereka bawa dari rumah. Dan juga plastik ataupun botol-botol sisa pestisida atau obat hama sering dibuang begitu spada kawasan TNKS yang nantinya dapat merusak keutuhan TNKS itu sendiri.

5. Masyarakat Gunung Tujuh masih melakukan kegiatan berburu hewan pada kawasan Taman Nasional Kerinci Seblat. Masyarakat yang bermata pencarian sebagai petani seringkali melakukan perburuan pada kawasan TNKS, hal ini dianggap biasa oleh masyarakat untuk memberantas hama hewan yang suka merusak tanaman pada ladang mereka. Adapun hewan yang diburu masyarakat yang bermata pencarian petani tersebut yaitu hewan babi yang sering sekali merusak tanaman petani.

6. Masyarakat bermata pencarian sebagai petani pada Kecamatan Gunung Tujuh yang bermata pencarian petani sudah melakukan kegiatan tebang pilih dalam pengambilan pohon pada kawasan Taman Nasional Kerinci Seblat. Apabila masyarakat mengambil kayu guna untuk membangun rumah atau masjid, masyarakat melakukan tebang pilih dalam pengambilannya, yaitu : kayu yang sudah tergolong tua dan layak untuk diambil.

7. Berdasarkan hasil penelitian yang telah penulis lakukan, masyarakat yang bermata pencarian sebagai petani mengemukakan bahwa mereka melakukan kegiatan seperti berladang pada kawasan TNKS karena disebabkan desakan ekonomi, masyarakat yang bermata pencarian sebagai petani tidak mempunyai mata pencarian lain ataupun area ladang yang lain untuk di garap sehingga masyarakat tetap nekat menggunakan lahan ladang mereka sekarang sebagai kawasan ladang guna memenuhi kebutuhan hidupnya. Masyarakat tetap melakukan penebangan pohon, karena masyarakat beranggapan kenapa mereka mesti membeli kayu untuk membangun sedangkan mereka tinggal pada daerah degan kayu yang ada disekelilingnya, sehingga dari pada membeli masyarakat lebih memilih untuk mengambilnya pada kawasan TNKS.

Masyarakat tetap melakukan pengembalaan hewan ternak mereka pada kawasan Taman Nasional Kerinci 
Seblat, karena mereka tidak mempunyai lahan lain kecuali kawasan hutan sebagai tempat mengembala ternak mereka. Karena pada kawsan hutan masyarakat memperoleh pangan untuk makan ternak mereka. Dan juga masyarakat masih tetap membuang benda-benda seperti sampah makanan, botol pestisida pada kawasan TNKS karena hal itu sudah dianggap biasa oleh masyarakat yang bermata pencarian sebagai petani.

Dari hasil penelitian di Kecamatan gunung Tujuh dapat disimpulkan bahwa masyarakat pada empat desa yaitu Desa Pelompek, Desa Pesisir Bukit, Desa Sungai Jernih, dan Desa Pauh Tinggi masih terdapatnya masyarakat yang bermata pencarian sebagai petani melakukan kegiatan negatif pada kawasan Taman Nasional Kerinci Seblat yaitu: masyarakat masih melakukan perladangan pada kawsan yang termasuk zonasi TNKS, masyarakat masih melakukan penebangan pohon, masyarakat masih melakukan perburuan hewan pada kawsan TNKS, dan yang terakhir masyarakat masih saja membuang sampah pada kawasan Taman Nasional Kerinci Seblat.

8. Temuan Lainnya. Mayarakat yang bermata pencarian petani tersebar pada 11 (sebelas desa) di Kecamatan Gunung tujuh, namun pada saat dilakukan penelitian, ternyata Desa Pelompek tempat dilakukannya penelitian telah memekarkan diri menjadi dua desa, yaitu Desa Sungai Jernih dan Desa Pelompek. Pada Desa Sungai Jernih masyarakatnya lebih menyadari pentingnya menjaga keutuhan TNKS karena masyarakat desa ini sudah melakukan reboisasi dibandingkan tiga desa lainnya.

Masyarakat yang bermata pencarian sebagai petani yang sejak dulu berladang pada areal kawasan Taman Nasional Kerinci Seblat menganggap bahwa pihak TNKS telah mengambil lahan mereka, sehingga antara warga masyarakat yang bermata pencarian sebagai petani tidak suka dengan petugas TNKS.

\section{SIMPULAN}

Berdasarkan hasil penelitian dan pembahasan yang telah dikemukakan sebelumnya, dapat disimpulkan bahwa:

1. Perilaku masyarakat yang bermata pencarian sebagai petani disebabkan oleh karena: a) area ladang petani diklaim sebagai kawasan Taman Nasional Kerinci Seblat oleh para petugas TNKS, padahal keberadaan masyarakat yang bermata pencarian sebagai petani, jauh sebelum adanya Taman Nasional Kerinci Seblat, b) areal ladang merupakan kawasan satusatunya yang dimiliki oleh masyarakat yang bermata pencarian sebagai petani, apabila pemerintah menggusur masyarakat dari ladang mereka, para petani berharap pemerintah menyediakan lahan 
yang lain untuk mereka garap. Guna memenuhi kebutuhan hidupnya sehari-hari.

2. Masyarakat melakukan kegiatan positif pada kawasan Taman Nasional Kerini Seblat hal ini dikarenakan masyarakat sudah mulai menyadari pentingnya akan keutuhan Taman Nasional guna kelangsungan hidup mereka, adapun bentuk-bentuk perilaku positif yang dilakukan masyarakat, yaitu: a) masyarakat sudah mulai melarang yang namanya pembukaan lahan baru, karena masyarakat takut ditangkap oleh petugas Taman Nasional Kerinci Seblat sehingga masyarakat tetap menggunakan lahan ladang peninggalan orang tua mereka yang dulu sebagai kawasan ladang mereka hingga saat ini, b) masyarakat yang bermata pencarian sebagai petani sudah melakukan yang namanya kegiatan reboisasi, meskipun dalam hal ini masyarakat yang bermata pencarian sebagai petani bekerjasama dengan KODIM guna mensukseskan program pemerintah dalam melakukan rebiosasi, c) masyarakat bermata pencarian sebagai petani pada Kecamatan Gunung Tujuh yang bermata pencarian petani sudah melakukan kegiatan tebang pilih dalam pengambilan pohon pada kawasan Taman Nasional Kerinci Seblat.
3. Masyarakat yang melakukan perbuatan negatif hal ini disebabkan dorongan dalam pemenuhan kebutuhan hidupnya. Masyarakat pun mengatakan bersedia pindah asalkan disediakan lahan lain sebagai ganti ladang mereka, namun hal tersebut hingga saat ini belum juga ada. Sehingga mendorong masyarakat untuk tetap berperilaku negatif. Adapun bentuk-bentuk perilaku negatif yang dilakukan masyarakat yaitu: a) masyarakat masih tetap saja menggunakan lahan yang termasuk zonasi kawasan Taman Nasional Kerinci Seblat sebagai ladang mereka, b) masyarakat pada Kecamatan Gunung Tujuh masih ada yang melakukan penebangan pohon pada kawasan TNKS, c) masih terdapatnya masyarakat Gunung Tujuh yang mengembalakan ternaknya pada kawasan Taman Nasional Kerinci Seblat, d) masyarakat Gunung Tujuh masih terdapat yang membuang benda-benda yang dapat merusak kawasan TNKS, e) masyarakat Gunung Tujuh masih melakukan kegiatan berburu hewan pada kawasan Taman Nasional Kerinci Seblat. 
DAFTAR PUSTAKA

Emzir. (2011). Metodologi Penelitian Kualitatif Analisis Data. Jakarta : Rajawali Pers.

Iswandi, (2009). Dampak Konversi Lahan Pertanian Menjadi Non Pertanian Terhadap Lingkungan Di Kota Padang. Laporan Penelitian Tidak Diterbitkan. Padang: FIS UNP
Moleong, L., J. (2005). Metodologi Penelitian Kualitatif. Bandung: Remaja Rosdakarya.

Neni. (1999). Partisipasi Masyarakat Pinggiran Hutan Terhadap Kelestarian Suaka Alam Selasih Talang Di Kecamatan Lembaga Jaya Kab. Solok. Laporan Penelitian Tidak di Terbitkan. Padang : FIS UNP 